\title{
ÍNDICE DE INCAPACITAÇÃo RELATIVA DA MUNIÇÃo CIVIL BRASILEIRA MAIS IMPORTANTE DO PONTO DE VISTA MÉDICO-LEGAL
}

\section{Abelardo de Oliveira BRITO}

Brito, A.O. Índice de incapacitação relativa da munição civil brasileira mais importante do ponto de vista médico-legal. São Paulo, 1988.46 p. Dissertação (mestrado) -Faculdade de Medicina da Universidade de São Paulo. Saúde, Ética \& Justiça, 4(1/2):61, 1999. [Resumo]

Resumo: Para avaliar o índice de incapacitação da munição civil brasileira mais importante do ponto de vista médico legal foram realizados disparos com revólveres e pistolas carregadas com munição. $25, .32$ e .38, contra alvos de gelatina balística e argila, situados à seis (6) metros de distância.
Verificou- se a presença de duas cavidades: a) cavidade temporária e b) cavidade permanente. $O$ índice de incapacitação foi aferido baseado na forma e profundidade da cavidade temporária que cada calibre produzia na argila. A cavidade temporária foi medida em volume e expressa em $\mathrm{ml}$.

Unitermos: Análise de vulnerabilidade. Ferimentos por arma de fogo/epidemiologia. Ferimentos por arma de fogo/ mortalidade. Médicos legistas, legislação \& jurisprudência. Medicina legal, legislação \& jurispridência.

Brito, A.O. An Avaliation of the relative incapacitation index (the stop ping power) of the Brazilian civil ammunition and its importance in forensic medicine. São Paulo, 1988.46 p. Dissertação (mestrado) Faculdade de Medicina da Universidade de São Paulo. Saúde, Ética \& Justiça, 4(1/2):61, 1999. [Abstract]
Abstract: In order to evaluate and establish the (6) meters. Measurements showed the presence of relative incapacitation index of the most important two cavities: a) a temporary cavity and b) a permanent brazilian civil ammunition shoots were performed cavity. The shape and the size of the temporary cavity against targets of argil and gellatin, at a range of six in argil was used to establish this index.

Keywords: Vulnerability analysis. Wounds, gunshot/epidemiology. Wounds, gunshot/mortality. Coroners and medical examiners/legislation \& jurisprudence. Forensic medicine/legislation \& jurisprudence.

\footnotetext{
${ }^{1}$ Mestre em Ciências (Medicina Legal) pela Faculdade de Medicina da Universidade de São Paulo. Endereço para correpondência: Rua Teodoro Sampaio, 115. 05405-000. São Paulo, SP.
} 